\title{
Slow Pyrolysis as a Method for the Destruction of Japanese Wireweed, Sargassum muticum
}

\author{
John J Milledge ${ }^{1}$, Alan Staple ${ }^{1} \&$ Patricia J Harvey ${ }^{1}$, \\ ${ }^{1}$ Faculty of Engineering \& Science, University of Greenwich, UK \\ Correspondence: John J Milledge, Algae Biotechnology Research Group, School of Science, University of \\ Greenwich at Medway, Central Avenue, Chatham Maritime, Kent, ME4 4TB, UK. Tel: 44-208-331-8871. \\ E-mail: j.j.milledge@gre.ac.uk
}

Received: December 21, 2015 Accepted: January 5, 2015 Online Published: January 29, 2015

doi:10.5539/enrr.v5n $1 \mathrm{p} 28$

URL: http://dx.doi.org/10.5539/enrr.v5n1p28

\begin{abstract}
Japanese wireweed, Sargassum muticum is an invasive species to Great Britain, which might be controlled by harvesting it for energy and chemicals. Pyrolysis is the thermal decomposition of the organic components of dry biomass by heating in the absence of air. The distribution of matter between solid, liquid and syngas depends on the biomass and the pyrolysis temperature and time. Slow pyrolysis with lower temperatures $\left(\sim 400^{\circ} \mathrm{C}\right)$ tends to produce more solid char. Pyrolysis char can be an effective soil ameliorant, a sequestration agent due to its stability or burned as a fuel.

The research attempts to answer the question: Could slow pyrolysis be an energy efficient means for the destruction of Japanese wireweed and produce a potential product, biochar? A simple test rig was developed to establish the yield of biochar, biocrude and syngas from the slow pyrolysis of Sargassum muticum. An energy balance was calculated using compositional data from the analysis of the seaweed feedstock, higher heating values (HHV) from bomb-calorimetry and literature values.

The energy required to heat $1 \mathrm{~kg}$ of dry seaweed by $400^{\circ} \mathrm{C}$ for slow pyrolysis was estimated at $0.5 \mathrm{MJ}$. The HHV of syngas and biocrude produced from the pyrolysis totalled 2.9 MJ. There is, therefore, sufficient energy in the biocrude and syngas fractions produced by the pyrolysis of seaweed to power the process and produce useful biochar, but insufficient energy for drying.
\end{abstract}

Keywords: Sargassum muticum, biochar, energy balance, pyrolysis, seaweed

\section{Introduction}

The environmental and economic impacts of biological invasions of non-native species were estimated to be in early part of the last decade $\sim$ US\$ 1.4 trillion per year, equivalent $5 \%$ of the world economy (Engelen \& Santos, 2009). The estimated cost of non-native species in the Great Britain for 2010 was $£ 1.7$ billion per year with the cost of invasive marine species to shipping and aquaculture estimated to be in excess of $£ 40$ million per year (Cook et al., 2013).

Sargassum muticum, Japanese wireweed, is native to the northwest Pacific region (Edwards et al., 2014). It first was 'introduced' outside of it natural range to British Columbia and has become the dominant species at the low-tide level in many areas on the west coast of North America (Fletcher \& Fletcher, 1975). It first appeared in Europe in the early 1970s, and is now found on shorelines from Norway to Portugal (Engelen \& Santos, 2009). Since its first recorded find in the UK, on the coast of the Isle of Wight, it has spread along the south-coast and around the British Isles (Davison, 2009; Gibson, 2011). It has been described as very invasive and perhaps the most 'successful' invasive species in the UK in terms of its rate of spread (Davison, 2009). Under the EU's Water Framework Directive the UK has identified it as a species of high priority (Davison, 2009).

It is causing considerable problems in certain areas of the Kent coast, especially on chalk ledges, and is spreading, possibly displacing native algae (Kent Wildlife Trust, 2006; Medway Swale Estuary Partnership, ND; The River Stour (Kent) Internal Drainage Board, 2012). The destruction of this seaweed is an issue in southern England and could have considerable financial and energy costs (CABI, 2011; Williams et al., 2010). The eradication of Sargassum muticum has been attempted and, although not successful, (Lodeiro, Cordero, Grille, Herrero, \& de Vicente, 2004) results in the need to dispose of large quantities of seaweed biomass (Davison, 2009). Although 
Sargassum muticum has been exploited for aquaculture in China (Liu, Pang, Gao, \& Shan, 2013) and as a traditional food in Korea (E. J. Yang, Ham, Lee, Lee, \& Hyun, 2013), there is currently no commercial exploitation of this biomass in Europe (Lodeiro et al., 2004). The valorisation of Sargassum muticum biomass for fuel and other products could encourage its harvesting and control.

One potential product could be biochar, defined as a solid material obtained from the carbonisation of biomass used to improve soil properties (Meyer, Glaser, \& Quicker, 2011). The difference between charcoal and biochar is primarily in the end use with charcoal being used as a fuel and biochar as a nonfuel (Tenenbaum, 2009). Biochar is produced by pyrolysis, the thermal decomposition of the organic component of dry biomass by heating in the absence of air (McKendry, 2002; Saidur, Abdelaziz, Demirbas, Hossain, \& Mekhilef, 2011). Pyrolysis can produce high volumes of fuel relative to the biomass feed and the process can be modified to favour the production of bio-oil, syngas or solid char (Miao, Wu, \& Yang, 2004). The distribution between solid, liquid and syngas depends on the biomass and the pyrolysis temperature and time. Lower temperatures (around $400{ }^{\circ} \mathrm{C}$ ) tend to produce more solid char (slow pyrolysis). Higher temperatures produce a higher proportion of liquid (biocrude) and gas. Pyrolysis processes can be classified by temperature and processing time. While there are no formal definitions, slow pyrolysis is characterised by long residence times (from minutes to days for solids) at low reactor temperatures $\left(<400{ }^{\circ} \mathrm{C}\right)$ with very low rates of heating $\left(0.01-2^{\circ} \mathrm{C} \mathrm{s}^{-1}\right)$ (Milledge \& Heaven, 2014; Peacocke \& Joseph, ND), with slow pyrolysis resulting in higher yields of char rather than the liquid or gaseous products from higher temperature process (Brennan \& Owende, 2010; Ghasemi et al., 2012). Charcoal was traditional produced in earth kilns with pyrolysis, gasification, and combustion processes occurring in kiln. However, biochar is now produced by slow pyrolysis in metal retorts, such as the Exeter retort (Rawle, 2014), where pyrolysis and combustion processes are physically separated (Meyer et al., 2011; Peterson \& Jackson, 2014), that could co-produce solid char, liquid bio-oil and pyrolysis gas.

Char from pyrolysis may be utilised directly as a sequestration agent due to its stability, burned as an industrial fuel, used in a variety of applications such as carbon nanotubes and agrochemicals or further upgraded to a hydrogen-rich fuel (Rowbotham, Dyer, Greenwell, \& Theodorou, 2012). During the last decade, biochar has received a lot of attention, both from scientists and policy makers as a soil enhancer to potentially increase agricultural yields and simultaneously sequester carbon to help mitigate climate change (Shackley \& Sohi, 2010; van der Kolk \& Zwart, 2013). In bioenergy-biochar systems (BEBCS) the evolved volatile and gaseous compounds from the pyrolysis of biomass, are utilised for biofuel or bioenergy production while the carbon-rich solid biochar is used as a soil improver (Woolf, Lehmann, Fisher, \& Angenent, 2014). Although, increasing biochar production entails a reduction in bioenergy obtainable per unit of biomass feedstock, a model of BEBCS for dry terrestrial biomass ( $<15 \%$ moisture) suggests that it could produce net energy and biochar (Woolf et al., 2014).

Research on the pyrolysis of microalgae is 'quite extensive' and has achieved reliable and promising outcomes (Marcilla, Catalá, García-Quesada, Valdés, \& Hernández, 2013), but there appears to be less work on seaweed and much of the work carried out has used fast rather than slow pyrolysis for the production of oil rather than char (Milledge \& Heaven, 2014; Milledge, Smith, Dyer, \& Harvey, 2014; Yanik, Stahl, Troeger, \& Sinag, 2013; Zhou, Zhang, Zhang, Fu, \& Chen, 2010). The char from the pyrolysis of algae, however, has been found to be an effective soil ameliorant and fertiliser and could be an additional revenue stream (Bird \& Benson, 1987), but the thermal behaviour of seaweeds is complex with a myriad of diverse reactions and thermolysis pathways (Rowbotham, Dyer, Greenwell, Selby, \& Theodorou, 2013). It is suggested considerable further study is required to discover if and how this could be exploited to commercialise seaweed for fuel and chemicals (Ross, Jones, Kubacki, \& Bridgeman, 2008). Could the destruction of the invasive species to the UK, Sargassum muticum, by slow pyrolysis be energy efficient and produce a valuable product biochar?

\section{Method}

\subsection{Species and Sample Collection}

Sargassum muticum (Japanese wireweed) (Figure 1), was collected as part of a project to remove it from the Kent coast during March 2014. It was harvested with the holdfast to prevent regrowth and had natural contaminants such as mud, sand, chalk, small animals, other seaweeds etc. Excess chalk attached to Sargassum muticum was removed from the holdfast dried and weighed. 


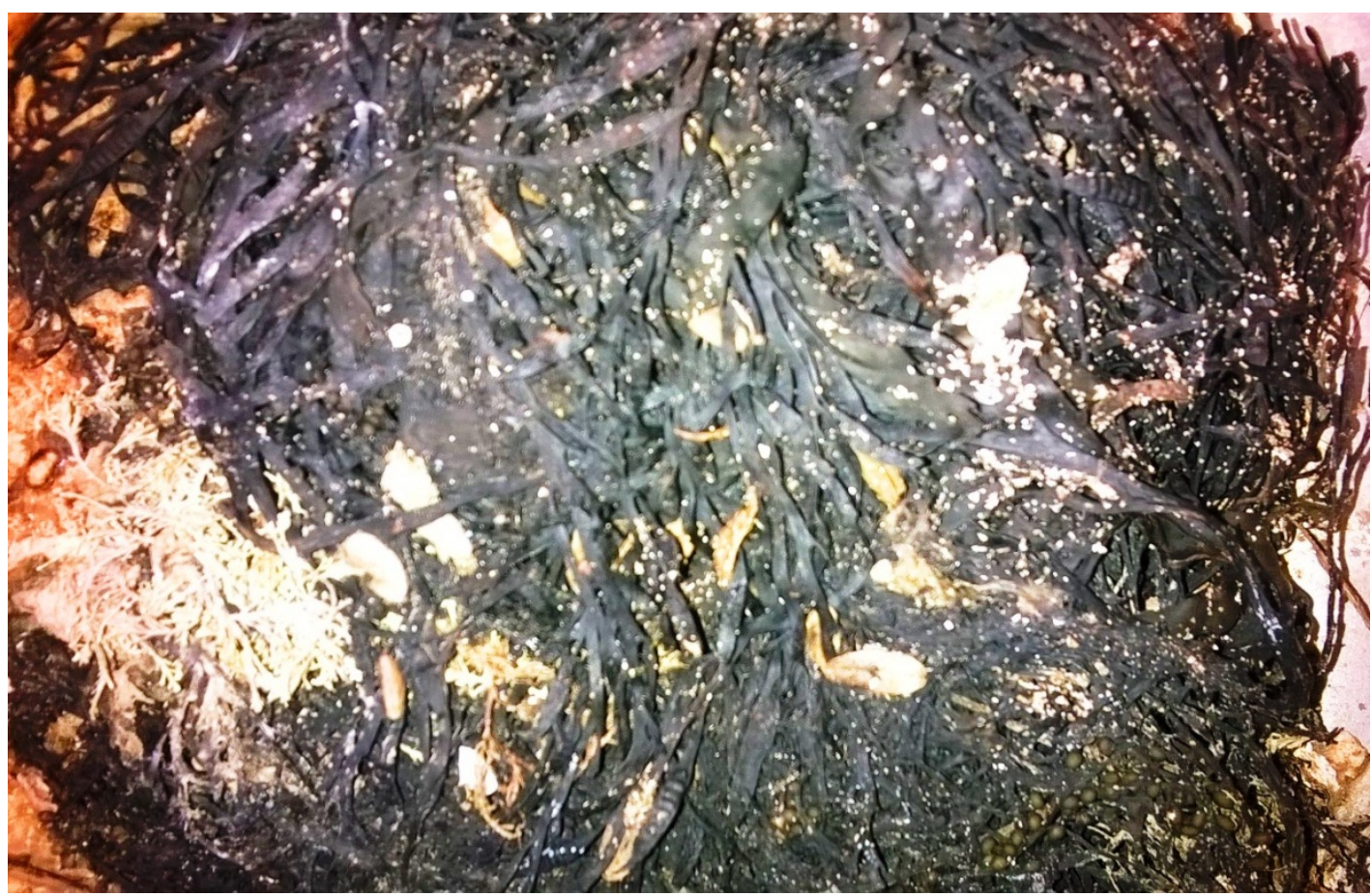

Figure 1. Dried Sargassum muticum showing natural contamination

Samples after collection were immediately placed in sealed bags and frozen and stored at $\leq 20^{\circ} \mathrm{C}$ on return to the laboratory within 24 hours. Moisture and ash determinations were carried out. Seaweed fronds showing minimum contamination were removed from oven dried samples $\left(105^{\circ} \mathrm{C}\right.$ for 24 hours $)$ and determination carried out to establish calorific value; and $\mathrm{C}, \mathrm{H}, \mathrm{S}, \mathrm{N}$ and ash content

\subsection{Dry Weight Determination}

The moisture content was established using the British Standards simplified oven drying method for the determination of moisture content in solid biofuels (BSI, 2009b). All measurements were repeated in triplicate and a mean value is reported. Samples after drying were stored in sealed container at $4{ }^{\circ} \mathrm{C}$ for further experimentation.

\subsection{Ash Determination}

The ash content of dried seaweed sample was measured using the British Standards method for determination of ash content in solid biofuels (BSI, 2009a). Again all measurements were carried out in triplicate and a mean value is reported. Ash was also examined by X-ray diffraction (XRD) analysis after grinding in a pestle and mortar to a fine powder $<10 \mu \mathrm{m}$

\subsection{Calorific or High Heating Value Determination}

Calorific values (CV) or Higher Heating Values HHV were measured using a Parr Model 1341 Bomb Calorimeter using the UKAS method for Determination of calorific value (BSI, 2010). The samples were oxidised by combustion in an adiabatic bomb containing oxygen under pressure and the HHV determined by measuring the temperature rise of a known mass of water. The dissolved sulphate and nitrate were calculated from titration to adjust for their contribution. A minimum of two determinations were carried out for each sample and a mean is reported.

\subsection{Elemental Analysis}

The carbon, hydrogen, nitrogen and sulphur content of the dried seaweed biomass were measured using Flash Dynamic Combustion (Flash EA1112 CHNS Elemental Analyser). The oxygen content was established by difference.

\subsection{Slow Pyrolysis}

Approximately $50 \mathrm{~g}$ of seaweed was subject to slow pyrolysis in a test-rig made from standard laboratory glassware, shown in Figure 2, which attempts to simulate the conditions in a commercial biochar retort, where biomass is heated externally in the absence of a flow of air. The temperature of the centre of seaweed biomass was taken at regular intervals during heating. The weight of initial dry seaweed, biochar and biocrude were measured. 
Gas was collected in pre-weighed 'Tedlar' bags and weighed. Total gas weight yield was calculated using relative density of the sample gas and laboratory air, established by the Royal Society of Chemistry method in which a syringe of known volume is weighed 'empty' and full with gas or air (Nuffield Foundation, 2014).

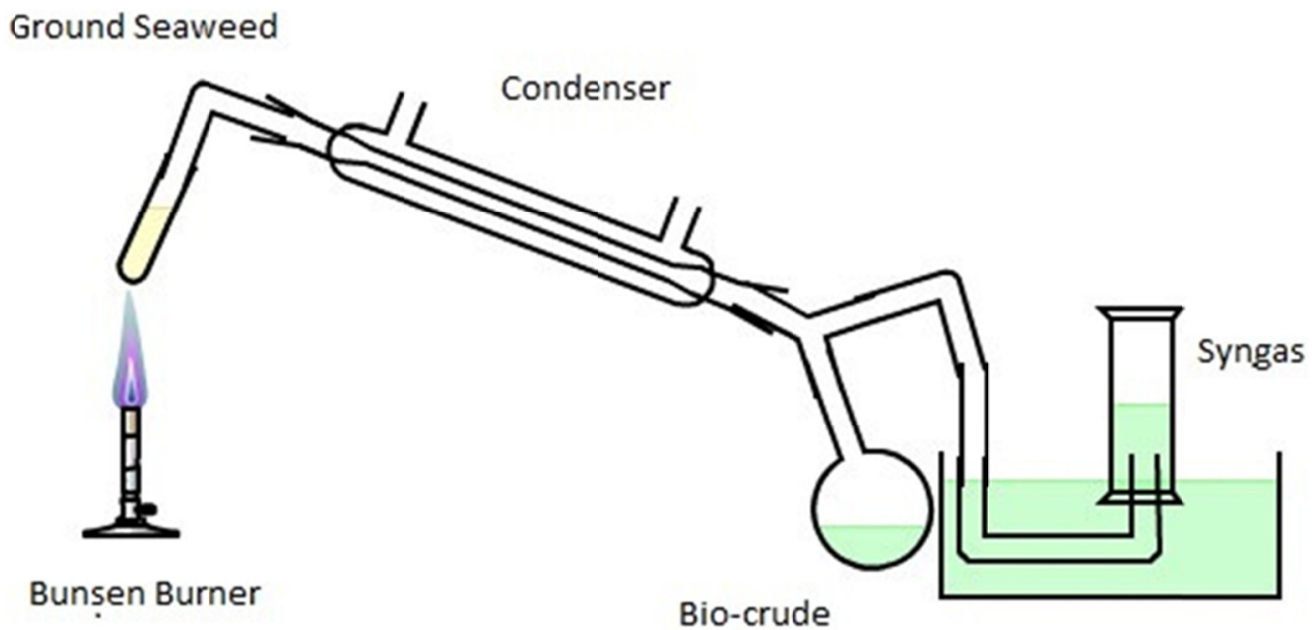

Figure 2. Slow Pyrolysis rig

\section{Results and Discussion}

\subsection{Seaweed Composition}

The moisture content of seaweed was found to be $79.9 \%$ (Standard Deviation (SD) $1.7 \%$ ). The average proximate analysis, ultimate analysis and higher heating value (HHV) of the dried Sargassum muticum is shown in Table 1.

Table 1. Compositional Analysis of Sargassum muticum

\begin{tabular}{llllll}
\hline Ash Carbon Hydrogen Oxygen Nitrogen Sulphur Higher Heating Value \\
\hline$\% \mathrm{dw} \% \mathrm{dw}$ & $\% \mathrm{dw}$ & $\% \mathrm{dw}$ & $\% \mathrm{dw}$ & $\% \mathrm{dw}$ & $\mathrm{MJ} \mathrm{kg}^{-1} \mathrm{dw}$ \\
29.4530 .66 & 3.95 & 29.56 & 4.89 & 1.49 & 16.4 \\
\hline
\end{tabular}

The compositional results are within the range reported in the literature for species of seaweed being considered as potential biofuels shown in Table 2 .

Table 2. Compositional data for species of seaweed being considered as potential biofuels

\begin{tabular}{llllllll}
\hline & Ash & Carbon & Hydrogen & Oxygen & Nitrogen & Sulphur & HHV \\
\hline & $\% \mathrm{dw}$ & $\% \mathrm{dw}$ & $\% \mathrm{dw}$ & $\% \mathrm{dw}$ & $\% \mathrm{dw}$ & $\% \mathrm{dw}$ & $\mathrm{MJ} \mathrm{kg}^{-1} \mathrm{dw}$ \\
\hline Fucus vesiculosus $^{l}$ & 22.82 & 32.88 & 4.77 & 35.63 & 2.53 & 2.44 & 15.0 \\
Chorda filum $^{l}$ & 11.61 & 39.14 & 4.69 & 37.23 & 1.42 & 1.62 & 15.6 \\
Laminaria digitata $^{l}$ & 25.75 & 31.59 & 4.85 & 34.16 & 0.9 & 2.44 & 17.6 \\
Fucus serratus $^{l}$ & 23.36 & 33.5 & 4.78 & 34.44 & 2.39 & 1.31 & 16.7 \\
Laminaria hyperborea $^{l}$ & 17.97 & 34.97 & 5.31 & 35.09 & 1.12 & 2.06 & 16.5 \\
Macrocyctis pyrifera $^{l}$ & 38.35 & 27.3 & 4.08 & 34.8 & 2.03 & 1.89 & 16.0 \\
Enteromorpha prolifera $^{2}$ & 30.1 & 28.75 & 5.22 & 32.28 & 3.65 & 0 & \\
Laminaria saccharina $^{3}$ & 24.2 & 31.3 & 3.7 & 36.3 & 2.4 & 0.7 & \\
1 $^{\text {(Ross et al., 2008) }}{ }^{2}$ (Zhou et al., $^{2010)}{ }^{3}$ (Anastasakis and Ross, 2011) & & \\
\hline
\end{tabular}


Sargassum muticum has a much higher ash content than typical potential terrestrial biomass crops (2-7 \%) (Ross et al., 2008) or wood (0.5-2 \%) (Misra, Ragland, \& Baker, 1993; Saidur et al., 2011). The high ash content of seaweed can provide both minerals and trace elements that are beneficial in both fertiliser and animal feed (McHugh, 2003; Philippsen, 2013), but ash content can be a considerable problem in direct combustion of biomass due to fouling of the boilers restricting the use of high ash content biomass (Demirbas, 2001). The metals in the ash of seaweed, however, have been shown to produce a significant catalytic effect on pyrolysis, and ash content (especially the potassium) strongly influences the product yields and bio-oil properties (Ross et al., 2008; Yanik et al., 2013). High potassium content caused high char yields and reduced bio-oil yields (Trinh et al., 2013; Yanik et al., 2013), but copper ions have been shown to promote the onset of pyrolysis in the alginate polymer and Laminaria digitata (Rowbotham et al., 2013). The result from XRD analysis of ash from Sargassum muticum is shown in Figure 3. Although the high temperature used to ash the seaweed $\left(550^{\circ} \mathrm{C}\right)$ may have converted some of the mineralogy to anhydrous crystal structures the data shows that the ash contains a large proportion of potassium compounds which may influence pyrolysis yields.

Sargassum muticum contains significantly higher levels of both sulphur and nitrogen typical found in terrestrial plants used for biofuels ( $<0.2 \%$ sulphur and $0.5-1 \%$ nitrogen) (Ross et al., 2008). High nitrogen and sulphur content in both macroalgae and microalgae has resulted in pyrolysis bio-oils containing nitrogen and sulphur compounds that require additional refining compared to those produced from terrestrial crops (Maddi, Viamajala, \& Varanasi, 2011; Wang, Wang, Jiang, Han, \& Ji, 2013)

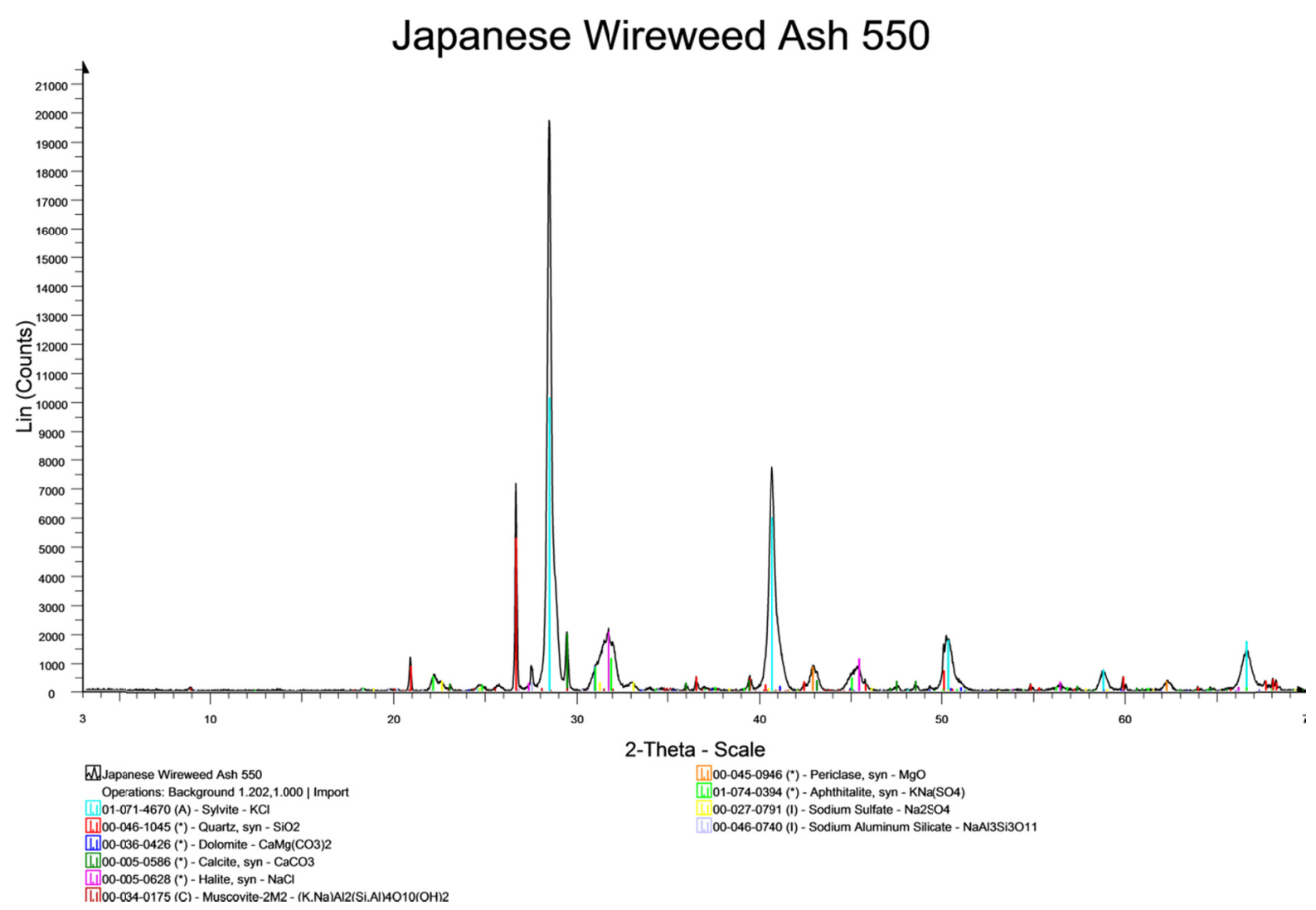

Figure 3. XRD analysis of ash produced from Sargassum muticum

\subsection{Pyrolysis}

The average temperature profile during pyrolysis of Sargassum muticum is shown in Figure 4. 


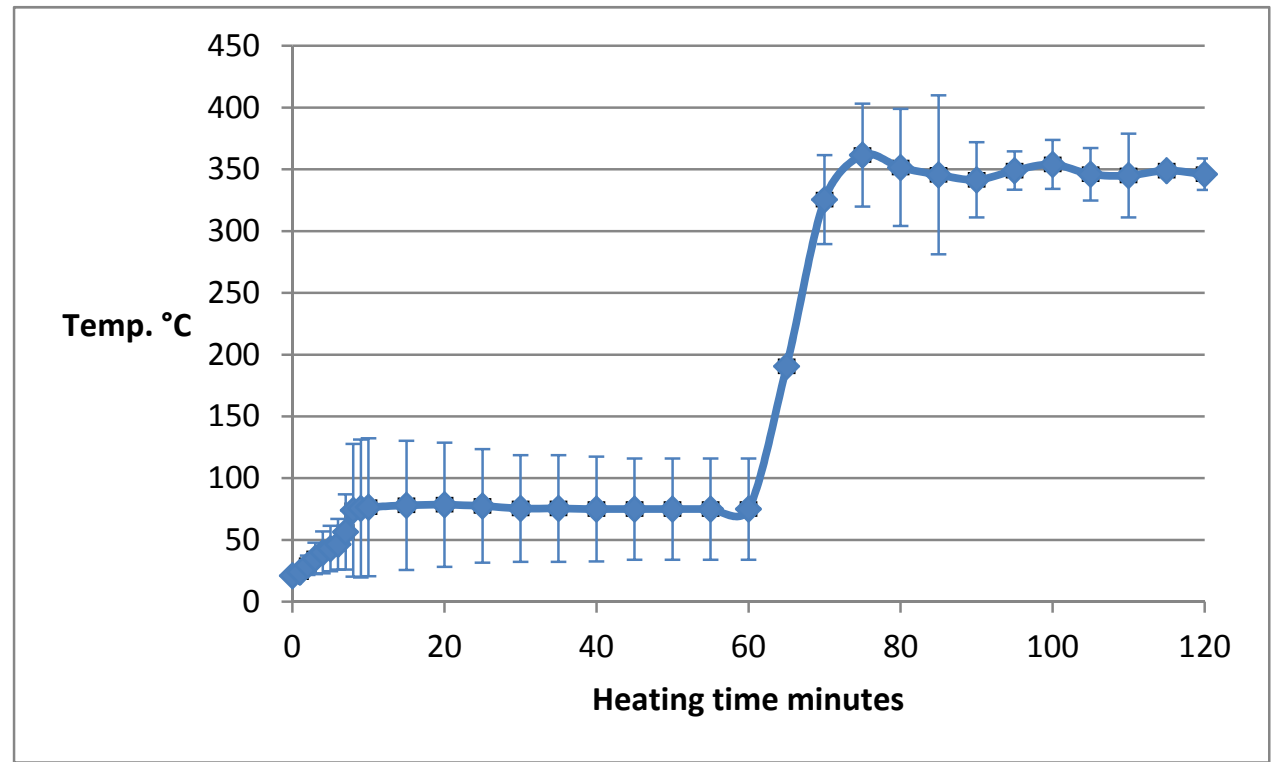

Figure 4. Average temperature profile during slow pyrolysis of oven-dried Sargassum muticum

The ash content of the dry seaweed used as feedstock for pyrolysis was higher $34.7 \%$ (SD $1.18 \%$ ) than that from seaweed fronds analysed (Table 1) due to natural contaminants such as mud, sand and chalk (Figure 1). The percentage weight yield and HHV of the pyrolysis products are shown in Table 3

Table 3. Percentage yield and HHV of the pyrolysis products

\begin{tabular}{lll}
\hline & $\%$ of original DW & $\mathrm{HHV}\left(\mathrm{MJ} \mathrm{kg}^{-1} \mathrm{dw}\right)$ \\
\hline Biochar & $67.6 \%$ & 15.7 \\
Syngas & $16.5 \%$ & \\
Biocrude & $11.3 \%$ & 15.6 \\
'Tar Hold-up' & $4.6 \%$ & \\
\hline
\end{tabular}

Some viscous brown residues remained in the test rig, due to the use of standard laboratory glassware, including expansion and reduction connections, in construction of the test-rig. It has been termed 'tar hold-up' in Table 3 . $79.9 \%$ of the tar hold-up was removed by rinsing in hexane leaving dark brown tar like deposits that were believed to be long molecular weight organic compounds (high molecular weight hydrocarbon are known to be insoluble in Hexane (EPA, 1998)).

The ash content of the biochar was found to be $52.4 \%$ (SD $1.8 \%$ ). Assuming that all the ash content remains within the biochar during pyrolysis this in close agreement with the calculated ash content of biochar of $51.5 \%$. HHV of the non-ash solids within the biochar, estimated from the measured HHV of the biochar and its ash content, is $33 \mathrm{MJ} \mathrm{kg}^{-1}$, which is in close agreement with HHV for graphite of $33 \mathrm{MJ} \mathrm{kg}^{-1}$ (Plummer, 1930) and typical wood charcoal of $32 \mathrm{MJ} \mathrm{kg}^{-1}$ (Misginna \& Rajabu, 2012) indicating that biochar is probably mainly comprised of carbon.

\subsection{Energy Balance}

The energy in $1 \mathrm{~kg}$ of Sargassum muticum, adjusting for the higher ash content of the samples pyrolysed compared to the sample used to establish HHV, was calculated at 15.2 MJ. Using the yield and HHV data in Table 3 the energy yield of biochar and biocrude from $1 \mathrm{~kg}$ of Sargassum muticum was calculated to be $10.6 \mathrm{MJ}$ and $2.6 \mathrm{MJ}$. Using the yield data in Table 3 for syngas and 'tar-hold-up' and typical HHV data for syngas $2.9 \mathrm{MJ} \mathrm{kg}^{-1}$ (McKendry, 2002) and bio-oil derived from the pyrolysis of algae $30.1 \mathrm{MJ} \mathrm{kg}^{-1}$ (C. Yang, Jia, Chen, Liu, \& Fang, 2011) the energy yield as syngas and 'tar-hold-up' from $1 \mathrm{~kg}$ of Sargassum muticum was estimated at $0.3 \mathrm{MJ}$ and $1.4 \mathrm{MJ}$. The total energy yield of the 4 pyrolysis products, biochar, biocrude, syngas and 'tar hold-up was $14.9 \mathrm{MJ}$ or $98 \%$ or the energy in the original seaweed prior to pyrolysis. A recent EU-Interreg funded project found energy 
yields of up to $96 \%$ for a range of 6 terrestrial biomass feedstocks and suggested that pyrolysis energy yields from biomass will be typically above $90 \%$ and always below $100 \%$ (Brownsort \& Dickinson, 2010).

Pyrolysis of biomass comprises both exothermic and endothermic processes, with the net enthalpy change of the pyrolysis chemical reactions being positive or negative, depending both on feedstock characteristics and process conditions with factors encouraging char formation such as those in slow pyrolysis tending to produce an overall process that is exothermic (Woolf et al., 2014). The specific heat of seaweed is $0.8-2.2 \mathrm{~J}^{0} \mathrm{~K}^{-1} \mathrm{~g}^{-1}$ (Wang et al., 2014 ) with the specific heat of low moisture or dry seaweed being reported as $1.3 \mathrm{~J}^{0} \mathrm{~K}^{-1} \mathrm{~g}^{-1}$ (Balingasa \& Elepaño, 2009; Sarbatly, Wong, Bono, \& Krishnaiah, 2010). Assuming no heat loss or gain as a result of reactions in pyrolysis (isoenthalpic reaction) and a specific heat of $1.3 \mathrm{~J}^{0} \mathrm{~K}^{-1} \mathrm{~g}^{-1}$ the energy required to increase the temperature of $1 \mathrm{~kg}$ of dry seaweed by $400^{\circ} \mathrm{C}$ in slow pyrolysis was estimated at $0.5 \mathrm{MJ}$. The HHV of syngas and biocrude produced from the pyrolysis totalled 2.9 MJ. There is, therefore, sufficient energy in the biocrude and syngas fractions produced by the pyrolysis of seaweed to power the process and produce useful biochar.

Drying is required prior to pyrolysis. The removal of water from the algal biomass by evaporation often requires considerable energy. To heat and evaporate water at atmospheric pressure from a temperature of $20^{\circ} \mathrm{C}$, requires an energy input of approximately $2.6 \mathrm{MJ} \mathrm{kg}^{-1}$ or over $700 \mathrm{kWh} \mathrm{m}^{-3}$ (Mayhew \& Rogers, 1972; Weast, 1985). To produce one kilogram of dry seaweed from seaweed containing $79.9 \%$ moisture will require the evaporation of $3.97 \mathrm{~kg}$ water and $10.3 \mathrm{MJ}$ of energy. Dryer typical efficiencies are $30-80 \%$ and vary with equipment, operating conditions and feed (Earle \& Earle, 1983). Tunnel dryers have an efficiency $\sim 50 \%$ (Mujumdar, 2007). The energy within the seaweed (15.2 MJ) would therefore be insufficient to remove the water from the wet seaweed to produce dry biomass for pyrolysis. This finding is in agreement with the results of a recent model of pyrolysis which suggest that high water content biomass $(>35 \%)$ will not be energy positive for the production of biochar and bioenergy due to the high energy requirement for drying the feedstock (Woolf et al., 2014).

Solar drying does not require fossil fuel energy, but is weather dependent and can cause considerable denaturation of organic compounds. It is the least expensive drying option (Brennan \& Owende, 2010), but large areas are required as only around $100 \mathrm{~g}$ of dry matter can be produced from each square metre of sun-dryer surface (Oswald, 1988). Sargassum muticum is unable to survive drying (Edwards et al., 2014) and therefore if sufficient areas of land adjacent to the areas from where it is to be removed could be found for solar drying there may be a low risk of the potential 're-infestation'.

\section{Conclusion}

There is sufficient energy in the biocrude and syngas fractions produced by the pyrolysis of seaweed to power the process and produce useful biochar. The high ash content of the biochar produced from the pyrolysis of seaweed, however, could restrict its use as a soil conditioning agent or as a charcoal fuel. There is insufficient energy within the seaweed for drying and solar drying or a similar low input-energy method prior to pyrolysis will be required

\section{Acknowledgements}

This work was supported by the EPSRC project number EP/K014900/1 (MacroBioCrude: Developing an Integrated Supply and Processing Pipeline for the Sustained Production of Ensiled Macroalgae-derived Hydrocarbon Fuels). Assistance of colleagues at the University of Greenwich: Dr Debbie Bartlett, Dr Ian Slipper, Mrs. Devyani Amin and Mr. Dudley Farman

\section{References}

Anastasakis, K., \& Ross, A. B. (2011). Hydrothermal liquefaction of the brown macro-alga Laminaria Saccharina: Effect of reaction conditions on product distribution and composition. Bioresource Technology, 102(7), 4876-4883. http://dx.doi.org/10.1016/j.biortech.2011.01.031

Balingasa, C. R., \& Elepaño, A. R. (2009). Studies on Engineering Properties of Red Seaweed (Kappaphycus spp.). Philippines Journal of Agriculture and Biosystems Engineering, 7, 59.

Bird, K. T., \& Benson, P. H. (1987). Seaweed cultivation for renewable resources. Bergen, Norway: Elsevier.

Brennan, L., \& Owende, P. (2010). Biofuels from microalgae--A review of technologies for production, processing, and extractions of biofuels and co-products. Renewable and Sustainable Energy Reviews, 14(2), 557-577. http://dx.doi.org/10.1016/j.rser.2009.10.009

Brownsort, P., \& Dickinson, D. (2010). Mass and Energy Balances for Continuous Slow Pyrolysis of Six Feeds and Production of Biochar for Characterisation Biochar: climate saving soils - Pyrolysis Studies Report: UKBRC, University of Edinburgh and LTCB, Ghent University.

BSI. (2009a). Solid biofuels -determination of ash content BS EN 14775:2009. 
BSI. (2009b). Solid biofuels. Determination of moisture content. Oven dry method. Total moisture. Simplified method BS EN 14774-2:2009.

BSI. (2010). Reaction to fire tests for products. Determination of the gross heat of combustion (calorific value) $B S$ EN ISO 1716:2010.

CABI. (2011). Sargassum muticum in Invasive Species Compendium. Retrieved from: http://www.cabi.org/isc/ datasheet/108973

Cook, E. J., Jenkins, S., Maggs, C., Minchin, D., Mineur, F., Nall, C., \& Sewell, J. (2013). Impacts of climate change on non-native species. MCCIP Science Review, 155-166. http://dx.doi.org/10.14465/2013.arc17. $155-166$

Davison, D. M. (2009). Sargassum muticum in Scotland 2008: a review of information, issues and implications. (Vol. Commissioned Report No.324 (ROAME No. R07AC707)): Scottish Natural Heritage.

Demirbas, A. (2001). Biomass resource facilities and biomass conversion processing for fuels and chemicals. Energy Conversion and Management, 42(11), 1357-1378. http://dx.doi.org/10.1016/S0196-8904(00)00137-0

Earle, R. L., \& Earle, M. D. (1983). Unit operations in food processing: NZIFST (Inc.).

Edwards, M., Hanniffy, D., Heesch, S., Hernández-Kantun, J., Queguineur, B., Ratcliff, J., Soler-Vila, A., \& Wan, A. (2014). Microalgae fact-sheets. Galway: NUI.

Engelen, A., \& Santos, R. (2009). Which demographic traits determine population growth in the invasive brown seaweed Sargassum muticum? Journal of Ecology, 97(4), 675-684. http://dx.doi.org/10.1111/j.1365-2745. 2009.01501.x

EPA. (1998). n-Hexane extractable material (hem) for sludge, sediment, and solid samples.

Fletcher, R. L., \& Fletcher, S. M. (1975). Studies on the Recently Introduced Brown Alga Sargassum muticum (Yendo) Fensholt I. Ecology and Reproduction. Botanica Marina, 18(3), 149-156. http://dx.doi.org/10.1515/ botm.1975.18.3.149

Ghasemi, Y., Rasoul-Amini, S., Naseri, A. T., Montazeri-Najafabady, N., Mobasher, M. A., \& Dabbagh, F. (2012). Microalgae biofuel potentials (Review). Applied Biochemistry and Microbiology, 48(2), 126-144. http://dx.doi.org/10.1134/S0003683812020068

Gibson, C. E. (2011). Northern Ireland State of the Seas Report: Agri-Food and Biosciences Institute.

Kent Wildlife Trust. (2006). Have you seen you seen these species on the shores around Kent or Sussex? http://dx.doi.org/10.1007/s00343-013-2314-9

Liu, F., Pang, S. J., Gao, S. Q., \& Shan, T. F. (2013). Intraspecific genetic analysis, gamete release performance, and growth of Sargassum muticum (Fucales, Phaeophyta) from China. Chinese Journal of Oceanology and Limnology, 31(6), 1268-1275. http://dx.doi.org/10.1007/s00343-013-2314-9

Lodeiro, P., Cordero, B., Grille, Z., Herrero, R., \& de Vicente, M. E. S. (2004). Physicochemical studies of cadmium(II) biosorption by the invasive alga in europe, Sargassum muticum. Biotechnology and Bioengineering, 88(2), 237-247. http://dx.doi.org/10.1002/bit.20229

Maddi, B., Viamajala, S., \& Varanasi, S. (2011). Comparative study of pyrolysis of algal biomass from natural lake blooms with lignocellulosic biomass. Bioresource Technology, 102(23), 11018-11026. http://dx.doi.org/10.1016/j.biortech.2011.09.055

Marcilla, A., Catalá, L., García-Quesada, J. C., Valdés, F. J., \& Hernández, M. R. (2013). A review of thermochemical conversion of microalgae. Renewable and Sustainable Energy Reviews, 27(0), 11-19. http://dx.doi.org/10.1016/j.rser.2013.06.032

Mayhew, Y. R., \& Rogers, G. F. C. (1972). Thermodynamic and Transport Properties of Fluids. Oxford: Blackwell.

McHugh, D. J. (2003). A guide to the seaweed industry FAO Fisheries Technical Paper FAO.

McKendry, P. (2002). Energy production from biomass (part 2): conversion technologies. Bioresource Technology, 83(1), 47-54. http://dx.doi.org/10.1016/S0960-8524(01)00119-5

Medway Swale Estuary Partnership. (ND). In The Water. Retrieved 22/04, 2014 from http://www.msep.org.uk/ invasive-species-in-the-water.php 
Meyer, S., Glaser, B., \& Quicker, P. (2011). Technical, Economical, and Climate-Related Aspects of Biochar Production Technologies: A Literature Review. Environmental Science \& Technology, 45(22), 9473-9483. http://dx.doi.org/10.1021/es201792c

Miao, X. L., Wu, Q. Y., \& Yang, C. Y. (2004). Fast pyrolysis of microalgae to produce renewable fuels. Journal of Analytical and Applied Pyrolysis, 71(2), 855-863. http://dx.doi.org/10.1016/j.jaap.2003.11.004

Milledge, J. J., \& Heaven, S. (2014). Methods of energy extraction from microalgal biomass: a review. Reviews in Environmental Science and Bio/Technology, 13(3), 301-320. http://dx.doi.org/10.1007/s11157-014-9339-1

Milledge, J. J., Smith, B., Dyer, P., \& Harvey, P. (2014). Macroalgae-Derived Biofuel: A Review of Methods of Energy Extraction from Seaweed Biomass. Energies, 7(11), 7194-7222. http://dx.doi.org/10.3390/en7117194

Misginna, M. T., \& Rajabu, H. M. (2012). Yield and Chemical Characteristics of Charcoal Produced by TLUDND Gasifier Cookstove Using Eucalyptus Wood as Feedstock. Paper presented at the Second International Conference on Advances in Engineering and Technology, Nagapattinam, India.

Misra, M. K., Ragland, K. W., \& Baker, A. J. (1993). Wood ash composition as a function of furnace temperature. Biomass \& Bioenergy, 4(2), 103-116. http://dx.doi.org/10.1016/0961-9534(93)90032-Y

Mujumdar, A. S. (2007). Handbook of Industrial Drying, (3 Ed.): CRC Press.

Nuffield Foundation. (2014). Determining relative molecular masses by weighing gases. Retrieved 2014, from http://www.nuffieldfoundation.org/practical-chemistry/determining-relative-molecular-masses-weighing-gases

Oswald, W. J. (1988). Large-scale algal culture systems (engineering aspects). In M. A. Borowitzka \& L. J. Borowitzka (Eds.), Micro-algal Biotechnology. Cambridge: Cambridge University Press.

Peacocke, C., \& Joseph, S. (ND). Notes on Terminology and Technology in Thermal Conversion. IBI Information papers. Retrieved April 15, 2014, from http://www.biochar-international.org/publications/IBI\#Pyrolysis guidelines.

Peterson, S. C., \& Jackson, M. A. (2014). Simplifying pyrolysis: Using gasification to produce corn stover and wheat straw biochar for sorptive and horticultural media. Industrial Crops and Products, 53, 228-235. http://dx.doi.org/10.1016/j.indcrop.2013.12.028

Philippsen, A. (2013). Energy Input, Carbon Intensity, and Cost for Ethanol Produced from Brown Seaweed. (MASc), University of Victoria,, Victoria, BC, Canada.

Plummer, W. B. (1930). Heat of Combustion of Carbon1. Industrial \& Engineering Chemistry, 22(6), 630-632. http://dx.doi.org/10.1021/ie50246a021

Rawle, R. (2014). Economics of Biochar. Paper presented at the Biochar Canterbury Christ Church, University.

Ross, A. B., Jones, J. M., Kubacki, M. L., \& Bridgeman, T. (2008). Classification of macroalgae as fuel and its $\begin{array}{llll}\text { thermochemical behaviour. Bioresource Technology, 99(14), 6494-6504. } & \text {. }\end{array}$ http://dx.doi.org/10.1016/j.biortech. 2007.11.036

Rowbotham, J. S., Dyer, P. W., Greenwell, H. C., Selby, D., \& Theodorou, M. K. (2013). Copper(II)-mediated thermolysis of alginates: a model kinetic study on the influence of metal ions in the thermochemical processing of macroalgae. Interface Focus, 3(1), 20120046. http://dx.doi.org/10.1098/rsfs.2012.0046

Rowbotham, J. S., Dyer, P. W., Greenwell, H. C., \& Theodorou, M. K. (2012). Thermochemical processing of macroalgae: a late bloomer in the development of third-generation biofuels? Biofuels, 3(4), 441-461. http://dx.doi.org/10.4155/bfs.12.29

Saidur, R., Abdelaziz, E. A., Demirbas, A., Hossain, M. S., \& Mekhilef, S. (2011). A review on biomass as a fuel for boilers. Renewable \& Sustainable Energy Reviews, 15(5), 2262-2289. http://dx.doi.org/10.1016/j.rser. 2011.02.015

Sarbatly, R., Wong, T., Bono, A., \& Krishnaiah, D. (2010). Kinetic and Thermodynamic Characteristics of Seaweed Dried in the Convective Air Drier. International Journal of Food Engineering, 6(5). http://dx.doi.org/10.2202/1556-3758.1600

Shackley, S., \& Sohi, S. (2010). An assessment of the benefits and issues associated with the application of biochar to soil: A report commissioned by the United Kingdom Department for Environment, Food and Rural Affairs, and Department of Energy and Climate Change.

Tenenbaum, D. J. (2009). Biochar: Carbon Mitigation from the Ground Up. Environmental Health Perspectives, 117(2), A70-A73. http://dx.doi.org/10.1289/ehp.117-a70 
The River Stour (Kent) Internal Drainage Board. (2012). Minutes of Board Meeting.

Trinh, T. N., Jensen, P. A., Dam-Johansen, K., Knudsen, N. O., Sorensen, H. R., \& Hvilsted, S. (2013). Comparison of Lignin, Macroalgae, Wood, and Straw Fast Pyrolysis. Energy \& Fuels, 27(3), 1399-1409. http://dx.doi.org/10.1021/ef301927y

van der Kolk, J., \& Zwart, K. (2013). Pyrolysis in the Countries of the North Sea Region.Potentially available quantities of biomass waste for biochar production: A publication of the Interreg IVB project Biochar: climate saving soils. http://www.biochar-interreg4b.eu/images/file/WP44\%20-\%20Pyrolysis\%20in\%20 the $\% 20$ Countries\%20of\%20the\%20North\%20Sea\%20Region.pdf

Wang, S., Jiang, X. M., Wang, Q., Ji, H. S., Wu, L. F., Wang, J. F., \& Xu, S. N. (2014). Research of specific heat capacities of three large seaweed biomass. Journal of Thermal Analysis and Calorimetry, 115(3), 2071-2077. http://dx.doi.org/10.1007/s10973-013-3141-0

Wang, S., Wang, Q., Jiang, X. M., Han, X. X., \& Ji, H. S. (2013). Compositional analysis of bio-oil derived from pyrolysis of seaweed. Energy Conversion and Management, 68, 273-280. http://dx.doi.org/10.1016/j. enconman.2013.01.014

Weast, R. C. (Ed.). (1985). Handbook of Chemistry and Physics. Boca Raton Fl: CRC.

Williams, F. E., Eschen, R., Harris, A., Djeddour, D. H., Pratt, C. F., Shaw, R. S., .. Murphy, S. T. (2010). The Economic Cost of Invasive Non-Native Species on Great Britain: CABI.

Woolf, D., Lehmann, J., Fisher, E. M., \& Angenent, L. T. (2014). Biofuels from Pyrolysis in Perspective: Trade-offs between Energy Yields and Soil-Carbon Additions. Environmental Science \& Technology, 48(11), 6492-6499. http://dx.doi.org/10.1021/es500474q

Yang, C., Jia, L. S., Chen, C. P., Liu, G. F., \& Fang, W. P. (2011). Bio-oil from hydro-liquefaction of Dunaliella salina over Ni/REHY catalyst. Bioresource Technology, 102(6), 4580-4584. http://dx.doi.org/10.1016/ j.biortech.2010.12.111

Yang, E. J., Ham, Y. M., Lee, W. J., Lee, N. H., \& Hyun, C. G. (2013). Anti-inflammatory effects of apo-9 '-fucoxanthinone from the brown alga, Sargassum muticum. Daru-Journal of Pharmaceutical Sciences, 21. http://dx.doi.org/10.1186/2008-2231-21-62http://dx.doi.org/10.1186/2008-2231-21-62

Yanik, J., Stahl, R., Troeger, N., \& Sinag, A. (2013). Pyrolysis of algal biomass. Journal of Analytical and Applied Pyrolysis, 103, 134-141. http://dx.doi.org/10.1016/j.jaap.2012.08.016

Zhou, D., Zhang, L., Zhang, S., Fu, H., \& Chen, J. (2010). Hydrothermal Liquefaction of Macroalgae Enteromorpha prolifera to Bio-oil. Energy \& Fuels, 24(7), 4054-4061. http://dx.doi.org/10.1021/ef100151h

\section{Copyrights}

Copyright for this article is retained by the author(s), with first publication rights granted to the journal.

This is an open-access article distributed under the terms and conditions of the Creative Commons Attribution license (http://creativecommons.org/licenses/by/3.0/). 